\title{
Observations of the lesser kestrel (Falco naumanni) in Bulgaria during the period of post-breeding dispersal
}

\author{
Pozorovania sokola bielopazúravého (Falco naumanni) v Bulharsku v pohniezdnom období
}

\author{
Girgina DASKALOVA, Peter SHURULINKOV, Georgi P. STOYANOV \& Borislav BORISOV
}

\begin{abstract}
The lesser kestrel (Falco naumanni) was considered extinct as a breeding species in Bulgaria, but recently a small breeding colony was found again in the south-eastern part of the country. Seven recent observations of flocks or solitary birds of the species in Bulgaria during the post-breeding period are presented and commented here. It is shown that the territory of the country is a regular area for post-breeding dispersal and pre-migratory feeding of lesser kestrels. The origin of these is not known, but most probably birds from the populations of the European part of Turkey, Greece, Republic of Macedonia and Albania are involved.
\end{abstract}

\begin{abstract}
Abstrakt: Sokol bielopazúravý (Falco naumanni) bol v Bulharsku považovaný za už nehniezdiaci druh, avšak nedávno bola $\mathrm{v}$ juhovýchodnej časti Bulharska nájdená jeho malá hniezdna kolónia. V príspevku je prezentovaných a komentovaných sedem aktuálnych pozorovaní skupín alebo samostatných jedincov druhu v Bulharsku v pohniezdnom období. Poukazuje to na to, že územie krajiny je druhom pravidelne využívané v období pohniezdnych potuliek a predmigračného dopíñania zásob. Pôvod pozorovaných jedincov nie je známy, ale najpravdepodobnejšie ide o vtáky z populácí́ z európskej časti Turecka, z Grécka, Macedónska a Albánska.
\end{abstract}

Key words: Balkan Peninsula, falcons, feeding habitat, pre-migratory concentrations

Girgina Daskalova, H. Dimitur 9, BG-8800 Sliven, Bulgaria. E-mail: girginand@gmail.com

Peter Shurulinkov, National Museum of Natural History,Bulgarian Academy of Science,Tsar Osvoboditel 1, 1000 Sofia, Bulgaria. E-mail: p.shurulinkov@gmail.com (corresponding author).

Georgi P. Stoyanov, Centre for conservation and support of wild fauna Durrell, Golyam Bratan 23, fl.2, ap.2, BG-1618 Sofia, Bulgaria. E-mail: georgips@abv.bg.

Borislav Borisov, Knyaz Dondukov 15, BG-6300 Haskovo, Bulgaria. E-mail: barsirbis@gmail.com.

Acknowledgements: We are grateful to our colleagues and friends Hristo Dinkov and Zdravko Hadzhijski, who joined us during part of the field work.

\section{Introduction}

The lesser kestrel (Falco naumanni) is a small colonial diurnal bird of prey widely distributed in the countries of Southern Europe - Spain, Portugal, Italy, France, Greece, Albania, Republic of Macedonia, Turkey, the countries in Transcaucasia and Ukraine (Birdlife International 2004). Recently it was found after a long period of absence as a breeder in Croatia (Mikulic et al. 2013). In Bulgaria the species disappeared as a breeder during the 1990s. Until 1997 cases of confirmed and probable breeding were reported in the Rhodopes Mts, Lomovete area, Western and Eastern Stara planina Mts, Mt. Sakar and South-western Bulgaria (Iankov et al. 1994, Iankov 2007, Barov et al. 2011), but after 2000 there were no more confirmed cases of nesting of the species across the country. In the past it was widely distributed in the country, most evidently in Southern Bulgaria with numerous breeding pairs (Patev 1950, Simeonov et al. 1990). According to a recent survey the actual breeding status of the species in Bulgaria is unclear (Kmetova et al. 2012). In 2014 a small breeding colony of lesser kestrels was found in the vicinity of Burgas, SE Bulgaria (Svetla Dalakchieva and Konstantin Popov, pers. communication; Gospodinov 2015, Gradev 2015).

The aim of the present work was to collect data on the post breeding occurrence of the lesser kestrel on the territory of Bulgaria and to contribute to the understanding of the species status in this country. 


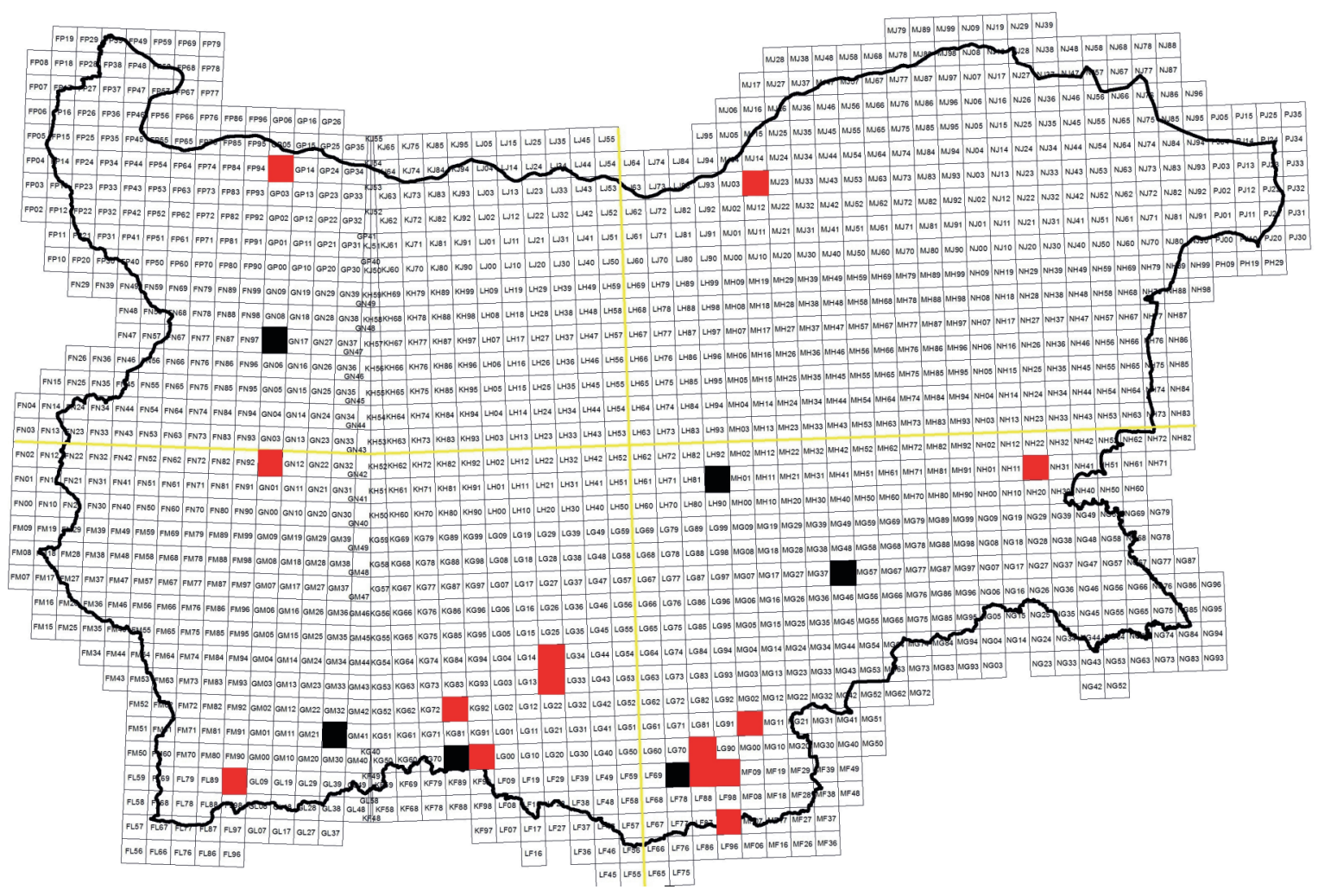

Fig.1. Locations of observations of lesser kestrels (Falco naumanni) in Bulgaria during breeding (red squares) and post-breeding (black squares) periods in 1994-2014.

Obr. 1. Lokalizácia pozorovaní sokola bielopazúravého (Falco naumanni) v Bulharsku $\vee$ hniezdnom (červené štvorce) a pohniezdnom (čierne štvorce) období v rokoch 1994 - 2014.

\section{Material and methods}

Observations of the lesser kestrel during the post-breeding period - July-September - were made in the territory of Bulgaria. We present observations made during the last 20 years, 1994-2014. We have not studied annually the whole territory of the country for the presence of lesser kestrels, but we have searched specifically for occurrence of this species in many suitable habitats in the following districts of Bulgaria: Sofia, Sliven, Yambol, Stara Zagora, Vratsa, Montana, Smolyan, Kurdzhali and Haskovo. We have also mapped the breeding avifauna in considerable parts of the following districts: Burgas, Pazardzhik, Blagoevgrad, Pleven, Rousse, Silistra, Shumen, Varna and Dobrich. During these studies we searched also for the presence of breeding lesser kestrels or for the existence of post-breeding concentrations of the species.

\section{Results}

Lesser kestrels were observed on seven occasions at five localities, with a total of 72 individuals during the period 1994-2014. Except for one observation of an individual in May, all the other records were made in the post-breeding period of the species, i.e. in AugustSeptember. The observations were made in South-eastern Bulgaria (districts of Yambol and Stara Zagora), Rhodopes Mts (district of Smolyan) and in North-western Bulgaria (district of Vratsa) (see Fig. 1). According to the existing published references there are also ten observations of the species in spring-summer during the period 1994-2014, mostly in Southern Bulgaria (Iankov 2007, Barov 2002, Barov et al. 2011) (Fig. 1). The frequency of observations during the breeding period showed a decreasing trend (Fig. 2).

On August 7, 1994 a group of nine lesser kestrels were observed at Chayirski Lakes, Western Rhodopes 


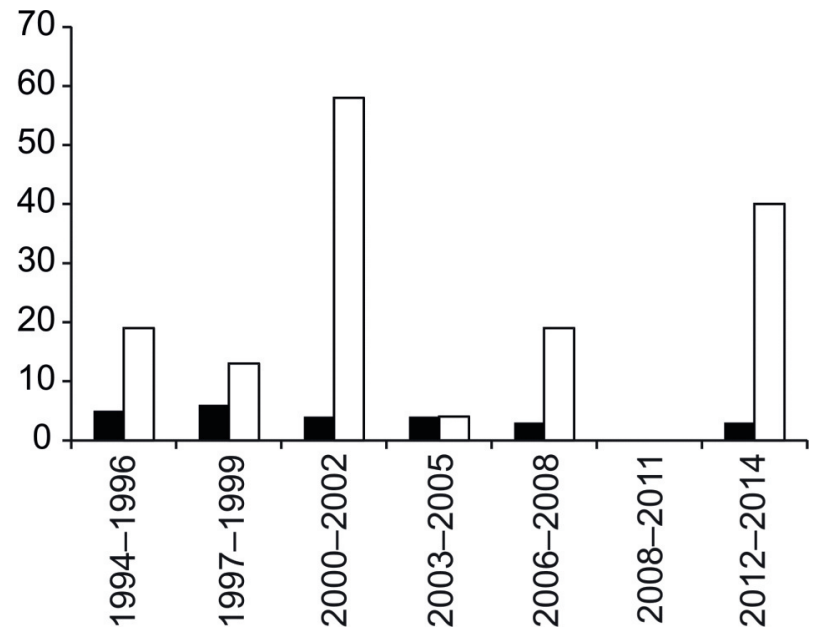

Fig 2. Number of published observations (black bars) and observed individuals (white bars) (including the present study) of lesser kestrel (Falco naumanni) during the breeding period and post-breeding dispersion in Bulgaria by three year periods in 1994-2014. Observations during the migration period along the Black Sea coastal flyway (via Pontica) and of lesser kestrels reintroduced after 2014 at Mt. Sakar are excluded.

Obr. 2. Počet publikovaných pozorovaní (čierne stípce) a pozorovaných jedincov (biele stípce) (vrátane tejto štúdie) sokola bielopazúravého (Falco naumanni) $v$ hniezdnom a pohniezdnom období $v$ Bulharsku počas trojročných období v rokoch 1994-2014. Pozorovania z obdobia migrácie pozdlž čiernomorskej t'ahovej cesty (via Pontica) a jedincov reintrodukovaných na horu Sakar po roku 2014 nie sú zahrnuté v tejto štúdii.

Mts, at 1,380 metres elevation, in Universal Transverse Mercator (UTM) square KG80. Of these birds four were adult males and five were females and juvenile birds. They were hunting giant grasshoppers on the mown meadows around the lakes. They used the power lines for perching and catching the insects.

On August 7, 1996 at the same locality 12 lesser kestrels were present. They were feeding again on grasshoppers, alternating their hunting place between three neighbouring meadows.

On August 17, 2005 in the city of Sliven, SE Bulgaria, local people brought us a wounded lesser kestrel originating from Nikolaevo in the Stara Zagora district. The bird had probably been injured by electrocution. It was a second-year male.

The lesser kestrel had the following body measurements: wing $-229 \mathrm{~mm}$, tail $-136 \mathrm{~mm}$, tarsometatarsus $-30 \mathrm{~mm}$. The first primary was $12 \mathrm{~mm}$. longer than the IV primary and $3 \mathrm{~mm}$. longer than the III primary.
On July 1, 2006 we visited the place of supposed origin of that lesser kestrel along the Tundzha River near Nikolaevo, at 273 metres elevation, UTM square LH91. We found a high river bank with a colony of sand martins (Riparia riparia), an occupied hole of a European roller (Coracias garrulus), and two small falcons: a female and a flying juvenile bird. We observed them from quite a long distance and it was not possible to recognize whether they were lesser or common kestrels (Falco tinnunculus).

On May 5, 2008 to the southwest of Mugla village in the Western Rhodopes Mts a second-year male lesser kestrel was observed. The bird was flying above a large mountain meadow at 1,802 metres elevation. The locality was situated $2.9 \mathrm{~km}$ to the north of the BulgarianGreek border, UTM square KG90.

On September 5, 2008 in an agricultural area to the south of the Manastirski Hills, SE Bulgaria (UTM square MG47) we observed a flock of 15 lesser kestrels. These birds were catching giant grasshoppers over a wheat field at 200 metres elevation. They were hunting mostly by perching on the power lines and swooping down, or by hovering. The first hunting method was performed in same manner as by the red-footed falcon (Falco vespertinus). Of the birds in the flock only one was adult male, all the others were females and firstyear birds. Two days later, on September 7, 2008, in the same area, a flock of 17 lesser kestrels were hunting again. Of these three birds were adult males, the rest were females and first-year birds.

The local people, owners of that field, confirmed that they had observed similar flocks of these birds hunting over their land in summer periods during the last $4-5$ years.

On August 3, 2013 a flock of 10 lesser kestrels was observed hunting actively over large pastures in Vrachanski Balkan Nature Park, Western Stara planina Mts, UTM square GN07. The area was situated between the peaks of Beglichka mogila (1,482 metres) and Purshevitsa $(1,427$ metres).The pastures were situated between 1,360 and 1,370 metres. That area is karst. Among the birds there was only one second-year male, the rest were females and first-year birds. The lesser kestrels were hunting giant grasshoppers, which were abundant in these pastures.

During the following year 2014, lesser kestrels were observed again in the same area between the peaks of Beglichka mogila and Purshevitsa, in Vrachanski Balkan Nature Park. On August 14, 2014 one adult male 
was observed and on August 15, 2014 two hunting adult males were seen. During August 2014 there were plenty of grasshoppers again in these pastures. The observed males were hunting together with up to 20 other falcons, most probably again lesser kestrels - females and first-year birds. Among them also solitary common kestrels (Falco tinnunculus) were spotted.

\section{Discussion}

The observations presented here indicate the presence of areas in Bulgaria used by lesser kestrels for postbreeding concentrations and pre-migratory feeding, mostly by first-year birds.

All the observations presented here except that in Mugla, Western Rhodopes are from August to the first half of September, which is the period between the end of the breeding season and the beginning of the lesser kestrels' autumn migration (Cramp 1980). That period is known to be the time for post-breeding dispersal and formation of pre-migratory flocks of lesser kestrels in different parts of their European breeding range, in Spain, Portugal, France, Italy and Albania (Olea 2001, Olea et al. 2004, Catry et al. 2011, Sara et al. 2014).

The observation of a solitary bird at Mugla, Western Rhodopes in May 2008 may refer to a wandering nonbreeding bird or late spring migrant. In Bulgaria summer flocks of lesser kestrels were also observed in June 2000, with three flocks numbering 23, 25 and 8 individuals found feeding in an area with swarms of grasshoppers in the Eastern Rhodopes (Barov 2002). A group of two adults and three juveniles was observed in Ognyanovo, Blagoevgrad district in August 1999 (Barov 2002).

In some places the post-breeding concentrations of lesser kestrels are quite numerous, annual and more or less permanent, for example in the Drino river valley in Albania with 4,000-6,000 individuals, at Badajoz, Spain with up to 3,500-4,000 individuals, in Appulia and Basciata, Italy with 10,138-16,764 individuals, and on the island of Sicily with 1,797-2,544 individuals (Minias et al. 2009, Sara et al. 2014). In the area to the north of the town of Kilkis in Northern Greece, 2,000 lesser kestrels were observed in August 1981 (Handrinos \& Akriotis 1997). These concentrations were in almost all cases in areas rich in grasshoppers, thus providing good feeding conditions for the lesser kestrels. They consisted mainly of juvenile, first-year birds and much fewer adult birds (Olea 2001, Sara et al. 2014). In the past such large concentrations of lesser kestrels also regularly formed in Bulgaria when the species was still a common breeder across the country. For example a flock of 40-50 lesser kestrels were observed feeding on pastures at Vurla Peak, Mt. Rila $(2,000$ metres) on August 23, 1961 (Liedel \& Luther 1969).

The observations presented here show that the territory of Bulgaria must still be included in the area of more or less permanent pre-migratory concentrations of lesser kestrels. The location of some of these places sheds additional light on the map of post-breeding dispersal of the lesser kestrel in Europe. The presence of post-breeding flocks of lesser kestrels probably facilitated the natural recolonization of the species recently reported in the vicinity of Burgas (Svetla Dalakchieva and Konstantin Popov, personal communication; Gospodinov 2015, Gradev 2015).

The question about the origin of the lesser kestrels observed in Bulgaria in the period of post-breeding dispersal is still open. Investigations based on colour ringing carried out in Spain show that the direction of post-breeding movements of juvenile lesser kestrels is predominantly northern, covering distances between 48 and $578 \mathrm{~km}$, and on average $210 \mathrm{~km}$ from the location of their nest sites (Olea 2001). Part of the juveniles and the adults in Spain remain at their nest sites or in close proximity to them even until the beginning of autumn migration. It was found using colour ringing and geolocators that the lesser kestrels from Southern Portugal disperse after the breeding period also mainly in a northerly direction, towards NW and NE Spain and Southern France, but part of them also remain in the breeding area until the start of the fall migration (Catry et al. 2011). In Italy pre-migratory flocks of lesser kestrels are often found feeding on insects (grasshoppers) in pastures (mainly in the Festuco-Brometalia habitat) at high elevations in the karst areas of the Central and Northern Apennines, where the species does not nest at all (Sara et al. 2014). Two lesser kestrels ringed during the breeding period on the island of Sicily were found later in this mountainous region in the period of post-breeding dispersal (Sara et al. 2014). It was supposed that during the post-breeding period the lesser kestrels fly mostly to the north and towards areas of higher elevation, because in the hottest summer time the numbers of insects is much higher in such areas compared to nesting areas situated in the lowlands (Olea 2001). Comparing these data we can assume that the lesser kestrels observed feeding in the Manastirski Hills most probably originated from colonies of the species in 
European Turkey, where recently a stable and numerous population was reported to exist (Kmetova et al. 2012). The lesser kestrels found feeding in Vrachanski Balkan Nature Park and in the Western Rhodopes Mts were most probably members of the species subpopulations in Greece (Thessaly, Macedonia) and Republic of Macedonia. But real confirmation of these hypotheses can be found only after conducting a comprehensive international study including colour ringing and setting geolocators on the juvenile lesser kestrels in their colonies in Greece, Turkey, Republic of Macedonia and Albania. Moreover the possibility cannot be excluded that some of the lesser kestrels observed in the present study originate from still existing small breeding localities in Bulgaria, such as the colony discovered in 2014 in the Burgas district (Svetla Dalakchieva and Konstantin Popov, personal communication; Gospodinov 2015, Gradev 2015).

\section{References}

Barov B 2002: Nacionalen plan za dejstvie za za opazvaneto na beloshipata vetrushka (Falco naumanni) v Balgaria, 2002-2006. [National Action Plan for protection of the lesser kestrel (Falco naumanni) in Bulgaria, 2002-2006], 161-182. In: Iankov P (ed), Svetovno zastrasheni vidove ptici v Balgaria. Nacionalni planove za dejstvie za opazvaneto im. Chast 1 [Globally threatened birds in Bulgaria. National Action Plans for their protection. Part 1]. Bulgarian Society for the Protection of Birds, Sofia, 227. [In Bulgarian]

Barov B, Marin S \& Ivanov I 2011: Lesser kestrel Falco naumanni Fleischer 1818, 83. In: Golemanski V (ed.), Red data book of Republic of Bulgaria, Bulgarian Academy of Science-MOEW, Sofia. 372. Retrieved August 21, 2015, from http://e-ecodb.bas.bg/rdb/en/vol2/Fanauman.html.

BirdLife International 2004: Birds in Europe: population estimates, trends and conservation status. BirdLife International, Cambridge, UK, 374.

Catry I, Dias MP, Catry T, Afanasyev V, Fox J, Franco A \& Sutherland W 2011: Individual variation in migratory movements and winter behaviour of Iberian lesser kestrels Falco naumanni revealed by geolocators. Ibis 153: 154-164. DOI: 10.1111/j.1474919X.2010.01073.X

Cramp S \& Simmons KE (eds) 1980: Handbook of the birds of Europe, the Middle East and North Africa. Vol. 2. Hawks to bustards. Oxford University Press.
Oxford, 695.

Gospodinov K 2015: Beloshipi vetrushki gnezdyat na teritoriyata na "Lukoil Neftohim" do Burgas [Lesser kestrels nest on the territory of "Lukoil Neftohim" at Burgas]. Retrieved August 21, 2015, from http://bspb.org/bg/news/Beloshipi-vetrushki-gnezdqtna-teritoriqta-na-Lukoil-Neftohim-do-Burgas.html.

Gradev G 2015: Izklyuchitelno redkite v Bylgariya beloshipi vetrushki gnezdyat na teritoriyata na „Lukoyl Neftohim Burgas" AD [Extremely rare in Bulgaria lesser kestrels nest on the territory of "Lukoil Neftohim Burgas" AD]. Retrieved August 21, 2015, from http:/greenbalkans.org/birdsofprey/lesserkestrellife/bg/Izklyuchitelno_redkite_v_Bylgariya_beloshipi_vetrushki_gnezdyat_na_teritoriyata_na_L ukoyl_Neftohim_Burgas_AD-p616.

Iankov PN (ed) 2007: Atlas of the breeding birds in Bulgaria. Bulgarian Society for Protection of Birds, Sofia, 679.

Iankov PN, Petrov T, Michev TM \& Profirov L 1994: Past and present status of the lesser kestrel Falco naumanni in Bulgaria, 133-137. In: Meyburg B-U \& Chancellor RD (eds), Raptor conservation today, The World Working Group on Birds of Prey and Owls, Berlin \& The Pica Press, London, 779.

Handrinos G \& Akriotis T 1997: The birds of Greece. Christopher Helm, London, 336.

Kmetova E, Zhelev P, Mechev A, Gradev G \& Ivanov I 2012: Natural colonies of lesser kestrel (Falco naumanni) in European Turkey and discussion on the chances of natural re-colonization of the species in Bulgaria. Acta Zoologica Bulgarica 64, suppl. 4: 45-52.

Liedel K \& Luther D 1969: Beitrage zur Avifauna Bulgariens. Beiträge zur Vogelkunde 14(6): 407-435. [in German]

Mikulic K, Budinski I, Čulina A, Jurinovic L \& Lucic V 2013: The return of the lesser kestrel Falco naumanni, as a breeding bird to Croatia. Acrocephalus 34: 71-74.

Minias P, Kaczmarek K, Piasecka A \& Kuncewicz M 2009: Large roost of lesser kestrel in south-eastern Albania. Journal of Raptor Research 43: 166-167.

Olea P 2001: Postfledging dispersal in the endangered lesser kestrel (Falco naumanni). Bird Study 48: 110-115. DOI: 10.1080/00063650109461208

Olea P, Vera R, De Frutos A \& Robles H 2004: Premigratory communal roosts of the lesser kestrel in the boreal summer. Journal of Raptor Research 38: 278-282. 
Patev P 1950: Pticite v Balgaria [The birds in Bulgaria]. BAS, Sofia, 364. [In Bulgarian]

Sara M, Campobello D, Zanca L \& Massa B 2014: Food and flight: pre-migratory dynamics of the lesser kestrel Falco naumanni. Bird Study 61: 29-41.
DOI: $10.1080 / 00063657.2013 .867476$

Simeonov SD, Michev TM \& Nankinov DN 1990: Fauna na Balgaria [Fauna of Bulgaria. Vol. 20. Aves]. Bulgarian Academy of Science, Sofia, 350. [In Bulgarian] 